\section{Jurnal Mitra Pendidikan (JMP Online)}

URL : http://e-jurnalmitrapendidikan.com
JMP Online

Vol. 4, No. 9, 611-619.

(C) 2020 Kresna BIP. e-ISSN 2550-0481

p-ISSN 2614-7254

\title{
PENERAPAN METODE JIGSAW UNTUK MENINGKATKAN HASIL BELAJAR SISWA PADA MATERI MULTIKULTUR ADALAH PEMBERIAN ALLAH DI KELAS XII IPA SMAN 1 ROTE SELATAN
}

\author{
Marny Aletha Saudale \\ SMAN I Rote Selatan
}

INFORMASI ARTIKEL

Dikirim : 12 Oktober 2020

Revisi pertama : 16 Oktober 2020

Diterima : 20 Oktober 2020

Tersedia online : 29 Oktober 2020

Kata Kunci: Jigsaw, Agama Kristen, Prestasi

Email: manry81@gmail.com
Tujuan yang hendak dicapai dalampenelitian ini adalah untuk meningkatkan prestasi belajar siswa kelas XII IPA pada pelajaran Agama Kristen materi multikultur adalah pemberian Allah dengan menerapkan metode jigsaw. Subyek penelitian tindakan kelas ini adalah siswa kelas XII IPA SMAN 1 Rote Selatan yang terdiri dari 31 orang.

Hasil penelitian menunjukan bahwa persentase aktivitas siswa pada siklus I adalah $48 \%$ dan meningkat pada siklus II menjadi $100 \%$, persentase ketuntasan belajar siswa pada siklus I adalah 58\% dan meningkat pada siklus II menjadi $100 \%$, persentase aktivitas guru pada siklus I adalah $62 \%$ dan meningkat pada siklus II mencapai $80 \%$.

Berdasarkan hasil penelitian yang dilakukan maka dapat disimpulkan bahwa melalui penerapan metode jigsaw pada pelajaran Agama Kristen materi multikultur adalah pemberian Allah untuk siswa kelas XII IPA SMAN 1 Rote Selatan dinyatakan berhasil. 


\section{PENDAHULUAN \\ Latar Belakang}

Pendidikan agama di sekolah formal merupakan bagian dari keseluruhan kegiatan di sekolah yang cukup penting dalam proses pembelajaran dan pembentukan watak peserta didik. Pendidikan agama diharapkan dapat membentuk peserta didik sebagai generasi terpelajar yang memiliki kecerdasan otak melalui pengetahuan umum dan pengetahuan keterampilan serta memiliki kecerdasan emosional dan spiritual melalui pendidikan agama. Dengan demikian, diharapkan pendidikan agama mengokohkan kepribadian peserta didik menjadi manusia yang utuh/sempurna. Strategi pengembangan pendidikan nasional dalam Undang-undang meletakkan pelaksanaan Pendidikan Agama pada urutan pertama, yaitu pendidikan agama dan akhlak mulia baru dilanjutkan dengan strategi lainnya. Pada penjelasan pasal 37 ayat (1) bahwa pendidikan Agama dimaksudkan untuk membentuk peserta didik menjadi manusia yang beriman dan bertaqwa kepada Tuhan Yang Maha Esa serta akhlak mulia (UU Sisdiknas, 2007).

Pendidikan agama Kristen memiliki peran yang amat penting dalam kehidupan umat kristiani. Melalui pendidikan agama setiap orang diupayakan agar mewujudkan suatu kehidupan yang bermakna, damai dan bermartabat. Menyadari bahwa perannya amat penting bagi kehidupan umat manusia, maka internalisasinya dalam kehidupan setiap pribadi menjadi sebuah keniscayaan, yang ditempuh melalui pendidikan, baik pendidikan di lingkungan keluarga, sekolah maupun masyarakat. Begitu pentingnya pendidikan agama kristen bagi setiap orang, namun berdasarkan permasalahan yang terjadi di kelas XII IPA SMAN 1 Rote Selatan, dimana siswa jarang terlibat dalam pembelajaran, dan karena bosan dengan penjelasan yang diberikan, ada sebagian siswa tidak lagi mendengarkan materi pembelajaran, malah bercerita dengan teman sebangku dan bahkan ada yang tertidur saat pelajaran sedang berlangsung. Diketahui bahwa hasil belajar siswa dapat dipengaruhi oleh strategi pembelajaran yang digunakan oleh guru di dalam kelas. Guru harus mampu memiliki strategi pembelajaran yang dianggap efektif, guru dituntut untuk memiliki kemampuan tentang penggunaan berbagai metode atau mengkombinasikan beberapa metode yang relevan. Ada kecenderungan perilaku guru dalam kegiatan pembelajaran lesu dan pasif. Perilaku semacam ini diakibatkan suatu proses pembelajaran yang tidak banyak melibatkan siswa, mengajar dengan serius, tidak mempergunakan media dalam penyampaian materi sehingga tidak terjadi interaksi dari hasil pembelajaran (Suwandi, 2006).

Untuk membantu meningkatkan keaktifan dan pemahaman peserta didik, maka peneliti mencoba menerapkan model pembelajaran tipe jigsawuntuk mengimbangi metode ceramah, dimana model pembelajaran jigsaw ini dalam pembelajarannya melibatkan peran aktif guru maupun peserta didik. Dari uraian di atas maka peneliti tertarik untuk melakukan penelitian dengan judul "Penerapan Metode Jigsaw untuk Meningkatkan Hasil Belajar Siswa pada Materi Multikultur Adalah Pemberian Allah di Kelas XII IPA SMAN 1 Rote Selatan".

\section{Rumusan Masalah}

Berdasarkan latar belakang yang telah diuraikan di atas maka masalah yang dikaji dalam penelitian ini adalah bagaimana Penerapan Metode Jigsaw untuk 
Meningkatkan Hasil Belajar Siswa pada Materi Multikultur adalah Pemberian Allah di Kelas XII IPA SMAN 1 Rote Selatan?

\section{Tujuan Penelitian}

Berdasarkan rumusan masalah di atas maka tujuan dari penelitian ini adalah untuk Mengetahui Penerapan Metode Jigsaw dalam Meningkatkan Hasil Belajar Siswa pada Materi Multikultur Adalah Pemberian Allah di Kelas XII IPA SMAN 1 Rote Selatan.

\section{KAJIAN PUSTAKA \\ Metode Jigsaw}

Secara etimologi, jigsaw berasal dari bahsa inggris yaitu gergaji ukir. Dalam pembelajaran, jigsaw mengambil pola cara bekerja sebuah gergaji yaitu siswa melakukan suatu kegiatan belajar dengan cara bekerja sama dengan siswa lain untuk mencapai tujuan bersama (Said dan Budimanjaya, 2016). Pembelajaran tipe jigsaw sudah berkembang dan diuji praktik pada tahun 1978 dari Eliiot Aronson dengan teman-temannya di Universitas Texas dan diadopsi oleh dari Slavin dengan teman-temannya dari Universitas Jhon Hopkins (Trianto, 2010).

Jigsaw merupakan pembelajaran yang membentuk kelompok kecil agar tercapainya tujuan pembelajaran, baik mandiri dan berkelompok. Jigsaw terdiri dari kelompok asal dan kelompok ahli. Penjelasan dari kelompok asal adalah seorang yang mempresentasikan hasil diskusi kelompok kepada perwakilan kelompok ahli. Sedangkan kelompok ahli adalah anggota dari kelompok asal. Setiap kelompok jigsaw terdiri dari 3-5 peserta didik, setiap kelompok memiliki tugas 1 kelompok asal dan sisanya adalah kelompok ahli. Setiap anggota kelompok jigsaw wajib bekerja sama agar tercapainya tujuan pembelajaran. Dan kesuksesan kelompok adalah penentu kesuksesan pembelajaran (Sanjaya, 2012).

\section{Materi Multikultur Adalah Pemberian Allah}

Istilah multikultural bersal dari kata "multi" artinya banyak, lebih dari satu dan kata "kultural" artinya budaya/kebudayaan. Multikultural dapat diartikan keragaman atau perbedaan antara suatu kebudayaan dan kebudayaan lain. Masyarakat Indonesia merupakan masyarakat multikultural artinya sekelompok manusia yang tinggal dan hidup menetap di suatu tempat yang memiliki kebudayaan dan ciri khas tersendiri yang mampu dibedakan dengan masyarakat lain. Setiap masyarakat memiliki kebudayaan yang berbeda dan akan menjadi ciri khasnya. Istilah lain adalah multikulturalisme yaitu pandangan atau kebijakan kebudayaan yang menekankan penerimaan terhadap adanya keragaman budaya, termasuk penghargaan serta penilaian atas budaya etnis orang lain.

\section{Sikap dan Respon yang Benar terhadap Multikultural}

Manusia memiliki kecenderungan untuk menjadikan persatuan dan kesatuan sebagai keseragaman dan kesamaan, namun adanya perbedaan tidak dapat dihindari, ketika anak-anak Nuh hendak mendirikan menara Babel agar mereka tidak terserak ke berbagai tempat, Allah justru melihat itu tidak boleh terjadi sehingga Allah mengacaukan bahasa mereka hingga mereka tidak bisa 
memahami bahasa sesamanya. Keberagaman inilah yang menyebabkan mereka terserak dan berpisah menurut bahasa masing-masing. Keadaan serupa dapat ditemui di Indonesia yang memiliki suku, bangsa, ras, etnis dengan budaya, bahasa dan tradisi yang berbeda.

Allah tidak pernah meniadakan multikultural sebab hal ini merupakan pemberian Allah yang akan memeperkaya manusia. Manusia mestinya mensyukuri segala perbedaan dengan hidup saling menghargai dan menerima, hal ini akan meniadakan perasaan dan sikap yang menempatkan kulturnya lebih tinggi daripada kultur lain. Mensyukuri kehidupan multikultural sebagai pemberian Allah menuntut sikap menempatkan diri sejajar dengan dirinya sendiri. Dengan sikap syukur tersebut, semua perbedaan dapat menjadi kekayaan yang membangun dan menekan semaksimal mungkin timbulnya konflik di antara manusia.

\section{Pengertian Hasil Belajar}

Hasil belajar merupakan perubahan perilaku yang diperoleh peserta didik setelah mengalami kegiatan belajar. Perolehan aspek-aspek perubahan perilaku tersebut tergantung pada apa yang dipelajari oleh peserta didik. Oleh karena itu apabila peserta didik mempelajari pengetahuan tentang konsep, maka perubahan perilaku yang diperoleh adalah berupa penguasaan konsep. Hasil belajar adalah pola-pola perbuatan, nilai- nilai, pengertian-pengertian, sikap-sikap, apresiasi dan keterampilan. Hasil belajar merupakan hasil dari suatu interaksi tindak belajar dan tindak mengajar. Dari sisi siwa hasil belajar merupakan berakhirnya penggal dan puncak proses belajar (Dimyati dan Mudjiono, 2006).

\section{METODE PENELITIAN}

\section{Tempat dan Waktu Penelitian}

Tempat Penelitian ini dilaksanakan di SMAN 1 Rote Selatan, Kecamatan Rote Selatan, Kabupaten Rote Ndao. Waktu Penelitian akan dilakukan pada bulan Agustus-September 2018. Subyek penelitiannya adalah siswa-siswi kelas XII IPA, dengan jumlah siswa sebanyak 31 orang.

\section{Jenis Penelitian}

Jenis penelitian ini adalah penelitian tindakan Kelas (PTK). Karakteristik dari penellitian ini merupakan tindakan tertentu untuk melihat sejauh mana proses pembelajaran dengan menggunakan metode jigsaw untuk meningkatkan hasil belajar siswa.

\section{Indikator Perbaikan Pembelajaran}

1) Segi proses: Pelaksanaan tindakan pemecahan masalah.

2) Segi hasil: Dampak dari tindakan pemecahan masalah.

\section{Teknik Pengumpulan Data}

1) Teknik pengumpulan data

Teknik pengumpulan data yang umum digunakan adalah teknik observasi. Intrumen pengumpulan data: pedoman observasi (berupa daftar cek, skala penilaian, catatan kejadian, dll). 
2) Tes

Instrumen pengumpulan data adalah soal tes yang valid dan dapat diandalkan

\section{Teknik Analisis Data}

1) Statistik deskriptif sederhana. Menghitung refleksi dan persentase hasil penelitian Siklus I dan siklus II:

a. Langkah-langkah pelaksanaan pembelajaran

b. Peran guru dalam pembelajaran

c. Keaktifan siswa dalam pembelajaran

d. Respon siswa tentang pelaksanaan pembelajaran maupun aspek hasil meliputi prestasi belajar

2) Deskripsi penelitian

Hasil penelitian dengan menggunakan pedoman observasi siklus pertama dan siklus kedua dideskripsikan secara verbal. Hasil observasi dibuat transkripsi observasi.

\section{HASIL PENELITIAN DAN PEMBAHASAN \\ Hasil Penelitian \\ Siklus I}

Guru observer melakukan pengamatan terhadap aktivitas belajar siswa. pelaksanaan pengamatan dilakukan selama jam pelajaran penuh. Berikut ini hasil pengamatan yang dilakukan selama proses pembelajaran pada siklus pertama.

Deskripsi Hasil Pengamatan terhadap Aktivitas Siswa Pada Siklus I

Tabel 1. Rekapitulasi Hasil Pengamatan Aktivitas Siswa Berdasarkan Kategori pada Siklus I

\begin{tabular}{|c|c|c|c|c|c|c|c|}
\hline \multirow{2}{*}{ No } & \multicolumn{4}{|c|}{ Kategori } & \multirow{2}{*}{ Interval } & \multirow{2}{*}{$\begin{array}{l}\text { Frekuensi } \\
(\mathbf{N})\end{array}$} & \multirow{2}{*}{$\begin{array}{c}\text { Presentase } \\
(\%)\end{array}$} \\
\hline & $\mathbf{A}$ & $\mathbf{B}$ & $\mathrm{C}$ & $\bar{D}$ & & & \\
\hline 1 & $\sqrt{ }$ & & & & - & - & - \\
\hline 2 & & $\sqrt{ }$ & & & 15 & 0,48 & 48 \\
\hline 3 & & & $\sqrt{ }$ & & 16 & 0,52 & 52 \\
\hline 4 & & & & $\sqrt{ }$ & - & - & - \\
\hline \multicolumn{5}{|c|}{ Jumlah } & 31 & 1 & 100 \\
\hline
\end{tabular}

Sumber : Hasil Penelitian, diolah (2018)

Keterangan Kategori:

$$
\begin{array}{ll}
\text { A } & =\text { Sangat baik } \\
\text { B } & =\text { Baik } \\
\text { C } & =\text { Cukup } \\
\text { D } & =\text { Kurang }
\end{array}
$$

Hasil pengamatan terhadap aktivitas siswa pada siklus I menunjukkan hasil yang belum begitu baik. Siswa mendengarkan penjelasan guru namun belum paham secara baik maksud dari materi yang diberikan. Pada siklus I ini aktivitas siswa yang masih kurang adalah di saat pelajaran berlangsung sebagian siswa lebih banyak tidak memperhatikan penjelasan materi yang diajarkan guru. Dengan melihat masalah yang dihadapi pada aktivitas siklus I ini maka nilai yang diperoleh pada kategori B sebanyak 15 orang dengan persentase mencapai $48 \%$ dan pada kategori $\mathrm{C}$ sebanyak 16 orang dengan persentase $52 \%$. 


\section{Analisis Indikator Keberhasilan Pada Siklus I}

Berdasarkan tabel 1, rekapitulasi hasil tes siklus I, peneliti menyimpulkan bahwa indikator keberhasilan pada siklus I masih belum baik dan perlu ditingkatkan lagi nilainya sampai mendapat nilai sangat memuaskan. Pada siklus I rentang nilai yang dicapai siswa adalah dari 60 sampai 80 .

Untuk menghitung persentase perolehan nilai siswa yang tuntas dapat dipakai rumus di bawah ini. Rumus yang dipakai dalam perhitungan indikator keberhasilan siswa adalah :

$$
P=\frac{\sum \text { Siswa yang tuntasbelajar }}{\sum \text { siswa }} \times 100 \%
$$

Tabel 2. Rekapitulasi Perolehan Nilai Siswa pada Siklus I

\begin{tabular}{|c|c|c|}
\hline No & Kategori & Jumlah \\
\hline 1 & Tuntas & 18 \\
\hline 2 & Tidak Tuntas & 13 \\
\hline 3 & Total Nilai & 2301 \\
\hline 4 & Rata-Rata & 74,22 \\
\hline 5 & Nilai Tertinggi & 80 \\
\hline 6 & Nilai Terendah & 60 \\
\hline 7 & Prosentase Ketuntasan & $58 \%$ \\
\hline
\end{tabular}

Sumber : Hasil Penelitian, diolah (2018)

Dari perhitungan hasil nilai diatas menunjukan bahwa jumlah siswa yang tuntas ada 18 orang dengan persentase ketuntasan kelas adalah $58 \%$ yang belum menunjukan persentase yang baik dan hasil nilai yang diperoleh belum maksimal karena sebanyak 13orang belum bisa mencapai KKM 79, maka perlu ditingkatkan lagi sehingga semua siswa bisa tuntas.

\section{Tahap Refleksi}

Berdasarkan hasil nilai pada siklus I dapat dinyatakan belum berhasil karena dari nilai yang diperoleh, ada sebanyak 13 siswa yang nilainya masih belum mencapai rata- rata standar KKM sehingga peneliti menyimpulkan perlu diadakan penelitian pada siklus II untuk memperbaiki prestasi nilai diatas KKM.

\section{Siklus II}

Pada siklus II ini, peneliti menerapkan tetap menerapkan model pembelajaran tipe jigsaw dengan membagi siswa dalam 5 kelompok, masingmasing kelompok terdiri dari 6-7. Dalam penelitian ini, guru menjelaskan materi multukultur adalah pemberian Allah kepada siswa. Dibentuk kelompok ahli (homogen) untuk diskusi pendalaman materi bahan ajar yang dibaca lalu kembali ke kelompok asal heterogen, siswa menjadi peer-tutor terhadap satu sama lain dan terjadi pembentukan secara berkelompok (social construction od knowledge).

Siswa dengan cermat mengikuti pelajaran sampai selesai. Siswa juga terlihat begitu semangat sama halnya dengan guru karena suasana kelas lebih hidup dan tidak membosankan bagi siswa. Kemudian dilakukan diskusi terbuka, sementara guru memberikan penguatan. Pada akhir pelajaran guru meyampaikan bahwa pada pertemuan kedua akan diadakan ulangan dan menyuruh siswa untuk 
belajar dengan baik. Dari hasil siklus II ini maka dapat kita lihat hasil pengamatan aktivitas siswa, guru dan indikator keberhasilan siswa pada pembahasan di bawah ini.

\section{Deskripsi Hasil Pengamatan terhadap Aktivitas Siswa Pada Siklus II Tabel 3. Rekapitulasi Aktivitas Siswa Berdasarkan Kategori Penilaian pada Siklus II}

\begin{tabular}{|c|c|c|c|c|c|c|c|}
\hline \multirow{2}{*}{ No } & \multicolumn{4}{|c|}{ Kategori } & \multirow{2}{*}{ Interval } & \multirow{2}{*}{$\begin{array}{l}\text { Frekuensi } \\
(\mathbf{N})\end{array}$} & \multirow{2}{*}{$\begin{array}{c}\text { Presentase } \\
(\%)\end{array}$} \\
\hline & $\mathbf{A}$ & B & $\mathrm{C}$ & D & & & \\
\hline 1 & $\sqrt{ }$ & & & & 20 & 0,65 & 65 \\
\hline 2 & & $\sqrt{ }$ & & & 11 & 0,35 & 35 \\
\hline 3 & & & $\sqrt{ }$ & & - & - & - \\
\hline 4 & & & & $\sqrt{ }$ & - & - & - \\
\hline \multicolumn{5}{|c|}{ Jumlah } & 31 & 1 & 100 \\
\hline
\end{tabular}

Sumber : Hasil Penelitian, diolah (2018)

Keterangan Kategori:

$\mathrm{A}=$ Sangat baik

$\mathrm{B}=$ Baik

C $=$ Cukup

$\mathrm{D}=$ Kurang

Berdasarkan tabel 3 di atas maka hampir semua siswa mengalami peningkatan yang lebih baik dan mengerti tentang materi yang diberikan. Pada siklus II ini dapat dikatakan bahwa motivasi belajar siswa meningkat dengan baik, terlihat semua siswa aktif dan bersemangat dalam pembelajaran yang dijelaskan guru dengan menerapkan metode eksperimen. Tidak ada lagi siswa yang berada pada kategori C. Dari 31 siswa yang ada dan dilihat berdasarkan tabel 3 maka yang berada pada kategori A sebanyak 20 orang dengan persentase $65 \%$ dan pada kategori B sebanyak 11 orang dengan persentase $35 \%$.

\section{Analisis Indikator Keberhasilan Pada Siklus II}

Hasil yang dicapai dalam ulangan seperti yang ditampilkan pada tabel 4 menunjukan bahwa semua siswa tuntas dengan mencapai nilai di atas KKM 79 yakni 80 sampai 90 .

Tabel 4. Rekapitulasi Perolehan Hasil Nilai Siswa Pada Siklus II

\begin{tabular}{|c|c|c|}
\hline No & Kategori & Jumlah \\
\hline 1 & Tuntas & 31 \\
\hline 2 & Tidak Tuntas & - \\
\hline 3 & Total Nilai & 2679 \\
\hline 4 & Rata-Rata & 90,09 \\
\hline 5 & Nilai Tertinggi & 90 \\
\hline 6 & Nilai Terendah & 80 \\
\hline 7 & Prosentase Ketuntasan & $100 \%$ \\
\hline
\end{tabular}

Sumber : Hasil Penelitian, diolah (2018)

Pada tabel di atas menunjukan bahwa hasil nilai siswa pada pelaksanaan siklus II semuanya tuntas mencapai KKM dengan nilai tertinggi adalah 90 dan nilai terendah adalah 80. Nilai rata-rata kelas meningkat dari 74,22 (siklus I) menjadi 90,09 . 


\section{Tahap Refleksi}

Aktivitas guru pada siklus II dan analisa pemahaman materi pada siklus II mengalami peningkatan ke arah yang lebih baik dan memenuhi analisis pencapaian indikator ketuntasan nilai mencapai 80 sampai 90 mencapai KKM 79, maka penelitian ini dihentikan pada siklus II karena motivasi belajar siswa meningkat dengan baik dan hasil belajar yang dicapaipun mengalami peningkatan dan tuntas. Kelemahan yang terjadi pada siklus I dapat diatasi dengan baik pada siklus II.

\section{Pembahasan}

Tabel 5. Rekapitulasi Persentase Aktivitas Siswa, Aktivitas Guru dan Persentase Ketuntasan pada Siklus I dan II.

\begin{tabular}{|c|l|c|c|}
\hline \multirow{2}{*}{ No } & \multicolumn{2}{|c|}{ Uraian } & \multicolumn{2}{|c|}{ Persentase Perolehan (100 \%) } \\
\cline { 3 - 4 } & & Siklus I & Siklus II \\
\hline 1 & Aktivitas Siswa & 48 & 100 \\
\hline 2 & Aktivitas Guru & 62 & 80 \\
\hline 3 & Ketuntasan Belajar & 58 & 100 \\
\hline 4 & Rata-rata & 74,22 & 90,09 \\
\hline
\end{tabular}

Sumber : Hasil Penelitian, diolah (2018)

Dalam penelitian ini peneliti menerapkan metode jigsaw pada materi multikultur adalah pemberian Allah. Dari hasil tabel aktivitas siswa pada siklus I mencapai $48 \%$ menunjukan bahwa masih ada kelemahan yang terjadi pada siswa dalam proses pembelajaran karena guru masih menerapkan pola lama yaitu masih bersifat ceramah sehingga siswa merasa bosan dan belum mengerti dan paham tentang materi yang diajarkan, sedangkan aktivitas guru pada siklus I dari tahap persiapan, penyajian materi, kegiatan inti sampai penutup cukup baik, hasil yang dicapai aktivitas guru mencapai 62\%, namun masih ada kelemahan yakni dalam proses pembelajaran masih monoton dan kurang memberikan kesempatan kepada siswa untuk bertanya atau mengerjakan soal di papan tulis.

Ketuntasan belajar siswa pada siklus I mencapai 58\%. Hal ini menunjukkan prestasi yang diperoleh siswa pada siklus I belum meningkat dimana ada 13 siswa yang nilainya belum mencapai nilai KKM 79. Hal ini karena guru dalam hal ini peneliti belum menerapkan metode jigsaw dalam proses pembelajaran materi multikultur adalah pemberian Allah. Sedangkan pada siklus II, persentase ketuntasan mencapai $100 \%$ yang menunjukan bahwa hasil yang dicapai pada siklus II meningkat dan tuntas karena peneliti telah menerapkan metode jigsaw dalam proses pembelajarandengan baik. Dari hasil yang dicapai pada siklus II yang telah meningkat dan tuntas ini maka tidak perlu mengadakan penelitian lagi ke siklus berikutnya.

\section{KESIMPULAN DAN SARAN}

\section{Kesimpulan}

Dari penelitian tindakan kelas yang telah dilaksanakan pada siswa kelas XII IPA SMAN 1 Rote Selatan, maka dapat ditarik kesimpulan bahwa dengan menerapkan metode jigsaw dalam pembelajaran Agama Kristen maka dapat 
meningkatkan motivasi dan prestasi belajar yang efektif pada materi multikultur adalah pemberian Allah bagi siswa yang bersangkutan.

\section{Saran}

1) Bagi siswa dan guru:

Diharapkan siswa lebih giat dalam belajar sehingga prestasi yang dicapai dapat meningkat dengan baik dan bagi guru dalam memberikan pembelajaran dapat menerapkan model pembelajaran sesuai dengan materi yang disampaikan dan agar guru lebih kreatif sehingga kualitas sebagai seorang guru dapat meningkat dengan baik juga.

2) Bagi Sekolah:

Diharapkan sekolah selalu mendukung para guru dalam melakukan penelitian tindakan sekolah dengan menerapkan berbagai model pembelajaran sehingga dapat menunjang mutu pendidikan di sekolah tersebut.

\section{DAFTAR PUSTAKA}

Suwandi. 2006. Prosedur Penelitian Tindakan Kelas. Kediri, Jawa Tengah.

Trianto. 2010. Model Pembelajaran Terpadu. Jakarta: PT. Bumi Aksara

Sanjaya, Wina. 2012. Penelitian Tindakan Kelas. Jakarta: Kencana

Siregar, Eveline dan Hartini Nara. Teori belajar dan Pembelajaran. Bogor: Ghalia Indonesia.

Dimyati dan Mudjiono. 2006. Belajar dan Pembelajaran. Jakarta: Rineka Cipta.

Undang-Undang Sistem Pendidikan Nasional. 2007. Yogyakarta. Pustaka Pelajar. 